\title{
Fumigant and repellent activities of different essential oils alone and combined against the maize weevil (sitophilus zeamais motschulsky)
}

\begin{abstract}
The insecticidal and repellent activity of five essential oils (EOs) was studied separately and in binary combinations against Sitophilus zeamais. Minthostachys verticillata $\mathrm{EO}$ showed the highest fumigant activity with a $\mathrm{LC}_{50}$ value of $28.2 \mu 1 / 1$ air. A moderate toxicity was observed with Eucalyptus globulus EO $\left(\mathrm{LC}_{50}=335.7 \mu 1 / 1\right.$ air), whereas the EOs from Aloysia citriodora, Coriandrum sativum and Mentha $s p$. did not show insecticidal effect at $600 \mu \mathrm{l} / 1$ air. All combinations that include $M$. verticillata $\mathrm{EO}$ showed strong fumigant activity with $\mathrm{LC}_{50}$ values lesser than $78 \mu \mathrm{1} / 1$ air. The co-toxicity coefficient (CCT) of M. verticillata and E. globulus EO combination indicating an aditive effect $(\mathrm{CTC}=119.1)$. Repellent activity was evaluated using twochoice olfactometer assay. All EOs and their combinations had repellent effect on adults of $S$. zeamais $(\mathrm{P}<0.05)$.
\end{abstract}

Keywords: biopesticides, fumigant toxicity, repellent effect, stored maize pest
Volume I Issue 7 - 2017

\author{
Julieta Soledad Arena, ${ }^{1,2,3}$ María Laura \\ Peschiutta, ${ }^{1,2}$ Helena Calvimonte,' Julio \\ Alberto Zygadlo ${ }^{1,2}$ \\ 'Departamento de Química, Universidad Nacional de Córdoba, \\ Argentina \\ ${ }^{2}$ CONICET-Universidad Nacional de Córdoba, Instituto \\ Multidisciplinario de Biología Vegetal (IMBIV), Argentina \\ ${ }^{3}$ Universidad Nacional de Córdoba, Argentina
}

\begin{abstract}
Correspondence: María Laura Peschiutta, Instituto Multidisciplinario de Biología Vegetal (IMBIV), CONICETUniversidad Nacional de Córdoba, Avenida Vélez Sarsfield 1611, X50I6GCA, Córdoba, Argentina, Tel +5435 II 520237 05, Emailmlaurapeschiutta@gmail.com
\end{abstract}

Received: November 23, 2017 | Published: December 22, 2017
Abbreviations: EO, essential oil; ANOVA, analysis of variance; CTC, co-toxicity coefficients; DDVP, 2,2-dichlorovinyl dimethyl phosphate; RI, retention index; GC-MS, gas chromatography-mass spectrometry; EI-MS, electron impact mass spectra; TI, toxicity index

\section{Introduction}

The maize weevil Sitophilus zeamais Motschulsky (Coleptera: Curculionidae) is a worldwide primary pest of stored maize. Both larvae and adults feed on corn grains reducing their weight, nutritional value, commercial value and germination rate. ${ }^{1}$ The damage produced on grains also favors the occurrence of secondary pests and fungi. ${ }^{1,2}$ Fumigation is the most widespread method to control stored-product pests, however the overuse of conventional fumigants including phosphine and methyl bromide has brought some problems such as the development of resistance by insects, environmental pollution and negative effects on non-target organisms and human health. ${ }^{3,4}$ Consequently, the interest in generating different strategies of control has been increased.

Essential oils (EOs) are complex mixtures of volatile secondary metabolites produced by aromatic plants. ${ }^{5}$ They constitute an important source of bioactive chemicals ${ }^{6}$ and provide interesting alternatives to conventional insecticides due to their limited persistence on the environment, low mammalian toxicity and low probability of generate resistance. ${ }^{7,8}$ Numerous studies have demonstrated that EOs have a great potential as insecticides and repellents. ${ }^{8,9}$ Furthermore, many EOs or their constituents were studied for their fumigant and repellent effect on maize pests, including $S$. zeamais. ${ }^{10-12}$

The activity of an EO generally depends on its major constituents, but sometimes the sum of the activities of individual constituents does not explain the overall activity of the oil, evidencing synergistic or antagonistic effects. ${ }^{13}$ These effects also occur among constituents of different EOs. ${ }^{14}$ Therefore, combinations of EOs could significantly enhance their biological activity. ${ }^{7,15}$ For example, Benelli et al. ${ }^{16}$ observed that the binary mixture of EOs from Satureja montana L. and Aloysia citriodora Palau has higher larvicidal toxicity than the individual oils against Culex quinquefasciatus Say.

The aim of the current study was to evaluate the fumigant and repellent activities of EOs from some locally available plants: Aloysia citriodora Palau (Verbenaceae), Coriandrum sativum L. (Apiaceae), Eucalyptus globulus Labill (Myrtaceae), Mentha sp. (Lamiaceae) and Minthostachys verticillata (Griseb.) Epling (Lamiaceae), separately and in binary combinations, against $S$. zeamais.

\section{Materials and methods}

\section{Essential oils}

Leaves of A. citriodora, E. globulus, Mentha sp. and M. verticillata and C. sativum seeds were collected in commercial crops in Córdoba, Argentina. The samples were air dried and subjected to hydrodistillation for 2 hours in a Clevenger's apparatus in order to extract their vaporized EOs, which were stored in dark glass tubes under refrigeration $\left(4^{\circ} \mathrm{C}\right)$ until evaluation.

Identification of the EOs constituents was determined using electron impact mass spectra (EI-MS) obtained from gas chromatography-mass spectrometry (GC-MS), and by co-injection of standards (Sigma Aldrich Co. Buenos Aires, Argentina), with the mass spectra libraries Adams, NIST and a homemade library being utilized. Compound concentrations were expressed as a percentage of the peaks area, and the retention index RI of each compound was obtained for a homologous series of n-alkanes $\mathrm{C}_{9}-\mathrm{C}_{20}$ (Sigma Aldrich Co. Buenos Aires, Argentina). Identifications were made by 
matching both their mass spectra and RI values with those reported in the literature and those of pure compounds, whenever possible. GCMS was performed on a GC-MS Perkin Elmer 600, equipped with a mass selective detector in the electron impact mode $(70 \mathrm{eV})$. The chromatography conditions being as follows: DB-5 capillary column ( $30 \mathrm{~m} \times 0.25 \mathrm{~mm}$, film thickness $0.25 \mathrm{~mm}$ ), the oven temperature was programmed linearly at $60^{\circ} \mathrm{C}$ for 5 minutes, ramped up to $170^{\circ} \mathrm{C}$ at $4^{\circ} \mathrm{C} /$ minute, and then to $240^{\circ} \mathrm{C}$ at $20^{\circ} \mathrm{C} /$ minute; injector temperature $250^{\circ} \mathrm{C}$; detector temperature $250^{\circ} \mathrm{C}$; carrier gas, $\mathrm{H}_{2}$ at $45 \mathrm{~cm} /$ second, split into $50 \mathrm{ml} /$ minute and samples of $1 \mu \mathrm{L}(1 / 100$ in $\mathrm{n}$-heptane, $\mathrm{v} / \mathrm{v})$ injected manually in the split-less mode.

\section{Insects}

Sitophilus zeamais adults were obtained from Metán, Salta, Argentina. Insects were maintained in sealed containers (10 1) with whole maize grains under controlled conditions $\left(26^{\circ} \mathrm{C}\right.$ and $60 \%$ relative humidity), in darkness. The colony was kept in our laboratory for two years without exposure to insecticides before testing. The unsexed adult weevils used in all the experiments were approximately 2 weeks old.

\section{Fumigant toxicity assay}

Susceptibility of $S$. zeamais adults to volatile compounds from $A$. citriodora, C. sativum, E. globulus, Mentha sp. and M. verticillata EOs and all their possibly binary combinations were evaluated using fumigant toxicity assay described by Peschiutta et al. ${ }^{17}$ with some modifications. Different doses $(10-600 \mu 1 / 1$ air) of the EOs or their combinations were applied to Whatman filter paper disks of $2 \mathrm{~cm}$ diameter placed on the underside of the screw cap of a fumigation chamber (30 ml-glass vial). The EOs was mixed in 1:1 ratio $(\mathrm{v} / \mathrm{v})$ in all binary combinations. A piece of voile was also placed under the screw cap to avoid direct contact of the weevils with the EOs. In each vial $5 \mathrm{~g}$ of whole maize grains were deposited in order to mimic the natural conditions in a silo. Ten adults of $S$. zeamais were placed in each fumigation chamber. Control treatments were performed without EO (negative control) and with 2,2-dichlorovinyl dimethyl phosphate (DDVP) at $0.06 \mu 1 / 1$ air (positive control). The assays were carried out in complete darkness at $28^{\circ} \mathrm{C}$ and $60 \pm 5 \%$ relative humidity. Five replicates per dose were performed and insect mortality was recorded at 24 hours. Co-toxicity coefficients (CTC) were calculated according to Sun et al. ${ }^{18}$ to evaluate the effect of the EO combinations. Considering that $\mathrm{C}$ indicates the combination of two EOs, and $\mathrm{A}$ and $\mathrm{B}$ indicates the combined EOs, the CTC were obtained using the following formulas:

Toxicity index of A (TI of A) (using A as standard) $=100$

Toxicity index of $\mathrm{B}(\mathrm{TI}$ of $\mathrm{B})=\mathrm{LC}_{50}$ of $\mathrm{A} / \mathrm{LC}_{50}$ of $\mathrm{B} \times 100$

Actual TI of $\mathrm{C}=\mathrm{LC}_{50}$ of $\mathrm{A} / \mathrm{LC}_{50}$ of $\mathrm{C} \times 100$

Theoretical TI of $\mathrm{C}=\mathrm{TI}$ of $\mathrm{A} \times$ proportion of $\mathrm{A}$ in $\mathrm{C}+\mathrm{TI}$ of $\mathrm{B} \mathrm{x}$ proportion of $\mathrm{B}$ in $\mathrm{C}$

\section{$\mathrm{CTC}=$ Actual TI of $\mathrm{C} /$ Theoretical TI of $\mathrm{C} \times 100$}

The EO which presented the lesser $\mathrm{LC}_{50}$ value was considered as the standard (A). CTC $<80,80<\mathrm{CTC}<120$ and $\mathrm{CTC}>120$ indicate antagonism, additive effect and synergism respectively. ${ }^{19}$

\section{Two-choice olfactometer assay}

The repellent activity of the EOs and their combinations were evaluated against $S$. zeamais. Behavioral response of $S$. zeamais adults to these compounds was measured using two-way olfactometer. ${ }^{20}$ Two $250 \mathrm{ml}$-Erlenmeyer were connected by a glass tube $30 \times 1 \mathrm{~cm}$ diameter in which was opened a small window $1 \times 1 \mathrm{~cm}$ equidistant from the two Erlenmeyer flasks. Corn kernels $(6 \mathrm{~g})$ and a filter paper of $2 \mathrm{~cm}$ diameter with the test compound (treatment) or with the solvent alone (control) were placed in each Erlenmeyer flask. The EOs and combinations were tested at $4 \mu 1 / 1$ air. Twenty insects deprived of food for at least 12 hours were placed in the center of the tube through the window made for that purpose, which subsequently was closed. The experiments were performed under dark conditions at $28^{\circ} \mathrm{C}$ and $60 \pm 5 \%$ relative humidity. The number of insects in each container was recorded after 90 minutes. The experiment was repeated five times per dose. For each test the response index (RI) was calculated with the following equation: $\mathrm{RI}=[(\mathrm{T}-\mathrm{C}) / \mathrm{Tot}] \times 100$, where $\mathrm{T}$ is the number responding to treatment, $\mathrm{C}$ is the number responding to control, and Tot is the total number of insects released. ${ }^{21}$ Positive RI indicates attraction to the treatment and negative RI indicates repellency.

\section{Statistical analysis}

The concentration-mortality data recorded after 24 hours of exposure to the EOs was subjected to a statistical analysis using the log-logistic model available in the "drc" package ${ }^{22}$ and compiled by the statistical software $\mathrm{R}^{\circledR} .{ }^{23}$ Lethal concentrations causing 50 and $95 \%$ of mortality $\left(\mathrm{LC}_{50}\right.$ and $\left.\mathrm{LC}_{95}\right)$ were determined, as well as their confidence limits at $95 \%$.

The significance of the mean RI in each treatment of the twochoice olfactometer bioassay was evaluated by the Student's t test for paired comparisons. ${ }^{21}$ Mean values of RI were first analyzed by analysis of variance (ANOVA) followed by a Dunnett's test $(\mathrm{P}<0.05)$.

\section{Results and discussion}

The composition of EOs from A. citriodora, C. sativum, E. globulus, Mentha sp. and M. verticillata are shown in Table 1. According to the analysis the main components were geranial (43.43 $\%)$ and nerol (28.89\%) in A. citriodora EO; linalool (93.81\%) in C. sativum EO; 1,8-cineole (32.18 \%) and p-cymene (17.04\%) in E. globulus EO; carvone (76.14\%) in Mentha sp. EO; and pulegone $(57.09 \%)$ and menthone $(36.36 \%)$ in M. verticillata EO.

The fumigant activity of the EOs and their binary combinations was evaluated against adults of $S$. zeamais. Minthostachys verticillata EO showed the highest fumigant toxicity with a $\mathrm{LC}_{50}$ value of $28.2 \mu \mathrm{l} / 1$ air (Table 2). A moderate toxicity was observed with E. globulus EO $\left(\mathrm{LC}_{50}=335.7 \mu \mathrm{l} / 1 \mathrm{air}\right)$, whereas the EOs from A. citriodora, C. sativum and Mentha sp. did not show fumigant activity at $600 \mu 1 / 1$ air. Similarly, Herrera et al. ${ }^{11}$ found that the EO from M. verticillata was the most bioactive among the tested EOs against $S$. zeamais, however they registered a higher $\mathrm{LC}_{50}$ value that could be attributed to the natural variation in the composition of the EOs. In another previous study M. verticillata EO also was the most toxic against Musca domestica L. equaling the $\mathrm{LC}_{50}$ of the reference insecticide DDVP. ${ }^{24}$ The strong fumigant toxicity of $M$. verticillata $\mathrm{EO}$ can be due to its elevated content of pulegone and menthone. ${ }^{11}$

Combinations of $M$. verticillata EO with the EOs from Mentha sp., E. globulus, C. sativum and A. citriodora showed high fumigant activity with $\mathrm{LC}_{50}$ values of $41.8,43.7,57.1$ and $77.6 \mu \mathrm{l} / 1$ air respectively (Table 2). On the other hand, all binary combinations of EOs from A. citriodora, C. sativum and Mentha sp. were not toxic 
against $\mathrm{S}$. zeamais at $600 \mu \mathrm{l} / \mathrm{l}$ air. Due to it was not possible to obtain the $\mathrm{LC}_{50}$ values of all the EOs and combinations, we could only calculate the CTC of $M$. verticillata and E. globulus EO combination $(\mathrm{CTC}=119.1)$, which indicates an additive effect. ${ }^{19}$

All the tested EOs and combinations had repellent effect on adults of $S$. zeamais $(\mathrm{P}<0.05)$ (Table 3$)$. Although there were no statistically significant differences among treatments, the combination of Mentha sp. and A. citriodora EOs showed the highest response index value $(-85.75 \pm 5.43)$. This value was even higher than those observed for Mentha sp. and A. citriodora EOs separately $(-56.40 \pm 10.13$ and $-44.67 \pm 17.72$ respectively), which could be due to the synergistic action of their main compounds. Similarly, Liu et al. ${ }^{25}$ found that

Table I Relative percentage concentrations of the components of the essential oils repellent activity of the mixture of EOs from Artemisia princeps Pamp and Cinnamomum camphora (L.) Presl. against adults of Sitophilus oryzae L. and Bruchus rugimanus Bohem was significantly higher than that elicited by individual oils. The mechanisms involved in how the interactions among the components of each EO result in the improvement of the repellent activity need further investigation. ${ }^{26}$

Summing up, $M$. verticillata EO alone or in combination with EOs from A. citriodora, C. sativum, E. globulus or Mentha sp. has strong fumigant activity, while all the tested EOs and combinations have repellent effect on adults of $S$. zeamais, offering interesting alternatives to traditional pesticides to control $S$. zeamais.

\begin{tabular}{|c|c|c|c|c|c|c|c|c|c|}
\hline $\begin{array}{l}\text { RI } \\
\text { (Literature) }\end{array}$ & $\begin{array}{l}\text { RI } \\
\text { (Calculated) }\end{array}$ & $\begin{array}{l}\text { Compound } \\
\text { names }\end{array}$ & $\begin{array}{l}\text { Minthostachys } \\
\text { verticillata }\end{array}$ & $\begin{array}{l}\text { Coriandrum } \\
\text { sativum }\end{array}$ & $\begin{array}{l}\text { Aloysia } \\
\text { citriodora }\end{array}$ & $\begin{array}{l}\text { Eucalyptus } \\
\text { globulus }\end{array}$ & & $\begin{array}{l}\text { lentha } \\
\text { p. }\end{array}$ & $\begin{array}{l}\text { Methods of } \\
\text { identification }\end{array}$ \\
\hline 924 & 928 & $\alpha$-thujene & & & & 2.33 & \multicolumn{3}{|c|}{ GC-MS, RI } \\
\hline 932 & 935 & $\alpha$-pinene & 0.27 & 0.8 & 0.17 & 0.83 & \multicolumn{3}{|c|}{ GC-MS, RI, Co } \\
\hline 969 & 972 & sabinene & 0.15 & & & & 0.32 & \multicolumn{2}{|c|}{ GC-MS, RI, Co } \\
\hline 974 & 973 & I-octen-3-ol & & & 2.71 & & & \multicolumn{2}{|c|}{ GC-MS, RI } \\
\hline 974 & 978 & $\beta$-pinene & 0.37 & & & 1.25 & 0.65 & \multicolumn{2}{|c|}{ GC-MS, RI, Co } \\
\hline 988 & 984 & $\beta$-myrcene & $\operatorname{tr}$ & & & 1.06 & 0.3 & \multicolumn{2}{|c|}{ GC-MS, RI } \\
\hline 1002 & 1005 & $\alpha$-phellandrene & & & & 9.68 & & \multicolumn{2}{|c|}{ GC-MS, RI } \\
\hline 1020 & 1023 & p-cymene & $\operatorname{tr}$ & 0.52 & 0.37 & 17.04 & $\operatorname{tr}$ & \multicolumn{2}{|c|}{ GC-MS, RI, Co } \\
\hline 1024 & 1027 & limonene & 0.86 & 0.97 & 4.56 & $\operatorname{tr}$ & 3.46 & \multicolumn{2}{|c|}{ GC-MS, RI } \\
\hline 1026 & 1032 & I,8-cineole & 0.31 & & & 32.18 & 5.19 & \multicolumn{2}{|c|}{ GC-MS, RI, Co } \\
\hline 1054 & 1056 & g-terpinene & & 1.44 & & 1.07 & & \multicolumn{2}{|c|}{ GC-MS, RI } \\
\hline 1086 & 1084 & terpinolene & & & & 0.34 & & \multicolumn{2}{|c|}{ GC-MS, RI } \\
\hline 1095 & 1093 & linalool & & 93.81 & & 1.51 & & \multicolumn{2}{|c|}{ GC-MS, RI } \\
\hline 1100 & 1103 & undecane & & & 0.23 & & & \multicolumn{2}{|c|}{ GC-MS, RI } \\
\hline 1137 & 1150 & cis-verbenol & & & 1.97 & & & \multicolumn{2}{|c|}{ GC-MS, RI } \\
\hline|| $4 \mid$ & $|15|$ & camphor & & 2.41 & & & & \multicolumn{2}{|c|}{ GC-MS, RI } \\
\hline 1148 & 1164 & menthone & 36.36 & & & & 0.22 & \multicolumn{2}{|c|}{ GC-MS, RI } \\
\hline 1158 & 1165 & isomenthone & 1.7 & & & 0.34 & & \multicolumn{2}{|c|}{ GC-MS, RI } \\
\hline 1159 & 1167 & menthofuran & & & & & 0.75 & \multicolumn{2}{|c|}{ GC-MS, RI } \\
\hline 1165 & 1177 & borneol & & & & & 0.49 & \multicolumn{2}{|c|}{ GC-MS, RI } \\
\hline 1167 & 1181 & isopulegone & 0.79 & & & & & \multicolumn{2}{|c|}{ GC-MS, RI } \\
\hline 1174 & 1184 & 4-terpineol & 0.12 & & & 5.89 & & \multicolumn{2}{|c|}{ GC-MS, RI } \\
\hline 1183 & 1193 & cryptone & & & & 9.13 & & \multicolumn{2}{|c|}{ GC-MS, RI } \\
\hline 1186 & $120 \mid$ & $\alpha$-terpineol & & & & 3.65 & & \multicolumn{2}{|c|}{ GC-MS, RI } \\
\hline 1191 & $120 \mid$ & cis-dihydrocarve & & & & & 2.2 & \multicolumn{2}{|c|}{ GC-MS, RI } \\
\hline 1193 & 1208 & dihydro carveol & neo-iso & & & & 0.46 & \multicolumn{2}{|c|}{ GC-MS, RI } \\
\hline 1226 & 1235 & carveol cis & & & & & 0.33 & \multicolumn{2}{|c|}{ GC-MS, RI } \\
\hline 1233 & 1240 & pulegone & 57.09 & & & $\operatorname{tr}$ & 0.41 & \multicolumn{2}{|c|}{ GC-MS, RI } \\
\hline 1235 & 1243 & neral & & & 28.89 & & & & IS, RI \\
\hline 1238 & 1249 & cuminaldehyde & & & & 2.16 & & $\mathrm{GC}$ & AS, RI \\
\hline 1239 & $|26|$ & carvone & & & & & 76.14 & & 1S, RI \\
\hline 1249 & 1266 & piperitone & 0.56 & & & & & & AS, RI \\
\hline
\end{tabular}

Citation: Arena JS, Peschiutta ML, Calvimonte H, et al. Fumigant and repellent activities of different essential oils alone and combined against the maize weevil (sitophilus zeamais motschulsky). MOJ Biorg Org Chem. 2017;I (7):249-253. DOI: 10.15406/mojboc.2017.01.00043 
Table Continued...

\begin{tabular}{|c|c|c|c|c|c|c|c|c|c|}
\hline $\begin{array}{l}\text { RI } \\
\text { (Literature) }\end{array}$ & $\begin{array}{l}\text { RI } \\
\text { (Calculated) }\end{array}$ & $\begin{array}{l}\text { Compound } \\
\text { names }\end{array}$ & $\begin{array}{l}\text { Minthostachys } \\
\text { verticillata }\end{array}$ & $\begin{array}{l}\text { Coriandrum } \\
\text { sativum }\end{array}$ & $\begin{array}{l}\text { Aloysia } \\
\text { citriodora }\end{array}$ & $\begin{array}{l}\text { Eucalyptus } \\
\text { globulus }\end{array}$ & & $\begin{array}{l}\text { Mentha } \\
\text { sp. }\end{array}$ & $\begin{array}{l}\text { Methods of } \\
\text { identification }\end{array}$ \\
\hline 1264 & 1274 & geranial & & & 43.43 & & \multicolumn{3}{|c|}{ GC-MS, RI } \\
\hline 1274 & 1285 & phellandral & & & & 1.97 & \multicolumn{3}{|c|}{ GC-MS, RI } \\
\hline 1283 & 1349 & $\alpha$-terpinen-7 al & 0.52 & & & & \multicolumn{3}{|c|}{ GC-MS, RI } \\
\hline 1374 & 1378 & $\alpha$-copaene & & & 0.29 & & & \multicolumn{2}{|c|}{ GC-MS, RI } \\
\hline 1387 & 1388 & $\beta$-bourbonene & & & 0.36 & & 0.88 & \multicolumn{2}{|c|}{ GC-MS, RI } \\
\hline 1410 & 1420 & $\alpha$-cedrene & & & & & 0.86 & \multicolumn{2}{|c|}{ GC-MS, RI } \\
\hline 1418 & 1426 & $\beta$-cariophyllene & & & 1.84 & & 2.78 & \multicolumn{2}{|c|}{ GC-MS, RI } \\
\hline 1434 & 1427 & g-elemene & & & & 1.42 & & \multicolumn{2}{|c|}{ GC-MS, RI } \\
\hline $145 \mid$ & 1460 & allo-aromadend & rene & & 0.35 & & & \multicolumn{2}{|c|}{ GC-MS, RI } \\
\hline 1452 & 1464 & $\alpha$-humulene & & & & & 0.25 & \multicolumn{2}{|c|}{ GC-MS, RI } \\
\hline 1454 & 1469 & cis $\beta$-farmasene & & & & & $\mathrm{tr}$ & \multicolumn{2}{|c|}{ GC-MS, RI } \\
\hline 1475 & 1477 & g-gurjunene & & & & & $\operatorname{tr}$ & \multicolumn{2}{|c|}{ GC-MS, RI } \\
\hline 1478 & 1480 & g-muurolene & & & & & 4.11 & \multicolumn{2}{|c|}{ GC-MS, RI } \\
\hline 1479 & $|48|$ & $\alpha$-curcumene & & & 2.3 & & & \multicolumn{2}{|c|}{ GC-MS, RI } \\
\hline 1484 & 1487 & germacrene $d$ & & & 0.46 & & & \multicolumn{2}{|c|}{ GC-MS, RI } \\
\hline 1522 & 1522 & $\delta$-cadinene & & & 0.4 & & & \multicolumn{2}{|c|}{ GC-MS, RI } \\
\hline 1577 & 1593 & spathulenol & 0.66 & & 4.35 & & & \multicolumn{2}{|c|}{ GC-MS, RI } \\
\hline 1582 & 1595 & $\begin{array}{l}\text { cariophyllene } \\
\text { oxide }\end{array}$ & 0.14 & & 5.8 & & & \multicolumn{2}{|c|}{ GC-MS, RI } \\
\hline 1677 & 1660 & nerolidol acetat & & & 1.51 & & & \multicolumn{2}{|c|}{ GC-MS, RI } \\
\hline & & Total & 99.9 & 99.95 & 99.99 & 91.85 & 99.8 & & \\
\hline
\end{tabular}

tr: traces $(<0.1 \%)$.

Table 2 Fumigant toxicity of the essential oils and their combinations against Sitophilus zeamais

\begin{tabular}{|c|c|c|c|c|c|}
\hline Essential oils & $\mathrm{LC}_{50}(\mu \mathrm{l} / \mathrm{I}$ air $)$ & 95\% CL ( $\mu \mathrm{l} / \mathrm{l}$ air $)$ & $L C_{95}(\mu \mathrm{I} / \mathrm{l}$ air $)$ & 95\% CL ( $\mu \mathrm{l} / \mathrm{l}$ air $)$ & $\left(X^{2}\right)^{a}$ \\
\hline Minthostachys verticillata & 28.2 & |8.4-43.| & 106.4 & $40.4-280.5$ & 13.45 \\
\hline Eucalyptus globulus & 335.7 & $250.3-450.3$ & 896.6 & $417.2-1927.0$ & 8.77 \\
\hline Mentha sp. & $>600$ & - & - & - & - \\
\hline Aloysia citriodora & $>600$ & - & - & - & - \\
\hline Coriandrum sativum & $>600$ & - & - & - & - \\
\hline M. verticillata+Mentha sp. & 41.8 & $31.1-56.3$ & 72.7 & $38.7-136.8$ & 2.5 \\
\hline M. verticillata+E. globulus & 43.7 & $32.4-58.9$ & 88 & $50.6-153.2$ & 39.05 \\
\hline M. verticillata $+C$. sativum & 57.1 & $43.7-74.6$ & 133.6 & $57.9-308.3$ & 6.71 \\
\hline M. verticillata $+A$. citriodora & 77.6 & $52.4-114.9$ & 262 & $71.2-964.2$ & 7.96 \\
\hline E. globulus+Mentha sp. & $>600$ & - & - & - & - \\
\hline E. globulus $+A$. citriodora & $>600$ & - & - & - & - \\
\hline E. globulus $+C$. sativum & $>300$ & - & - & - & - \\
\hline Mentha+A. citriodora & $>600$ & - & - & - & - \\
\hline Mentha+C. sativum & $>600$ & - & - & - & - \\
\hline A. citriodora+C. sativum & $>600$ & - & - & - & - \\
\hline
\end{tabular}

${ }^{a}$ Chi-square values, significant at $\mathrm{P}<0.05$ level

$\mathrm{CL}$ : confidence limits

Citation: Arena JS, Peschiutta ML, Calvimonte H, et al. Fumigant and repellent activities of different essential oils alone and combined against the maize weevil (sitophilus zeamais motschulsky). MOJ Biorg Org Chem. 20I7;I (7):249-253. DOI: I0.15406/mojboc.2017.01.00043 
Table 3 Response of Sitophilus zeamais to five essential oils and their binary combinations at $4 \mu \mathrm{l} / \mathrm{l}$ air in a two-choice olfactometer bioassay

\begin{tabular}{ll}
\hline Essential oils & Response index (RI) \\
\hline Coriandrum sativum & $-72.04 \pm 13.03 * * \mathrm{a}$ \\
Eucalyptus globulus & $-71.90 \pm 5.75 * * * \mathrm{a}$ \\
Mentha sp. & $-56.40 \pm 10.13 * * \mathrm{a}$ \\
Aloysia citriodora & $-44.67 \pm 17.72 * * \mathrm{a}$ \\
Minthostachys verticillata & $-38.40 \pm 11.64 * \mathrm{a}$ \\
A. citriodora + C. sativum & $-78.33 \pm 1.67 * * * \mathrm{a}$ \\
E. globulus + A. citriodora & $-67.34 \pm 6.30 * * * \mathrm{a}$ \\
E. globulus + C. sativum & $-48.03 \pm 5.41 * * \mathrm{a}$ \\
E. globulus + Mentha sp. & $-74.08 \pm 3.22 * * * \mathrm{a}$ \\
M. verticillata + A. citriodora & $-61.18 \pm 2.33 * * * \mathrm{a}$ \\
M. verticillata + C. sativum & $-55.85 \pm 8.95 * * \mathrm{a}$ \\
M. verticillata + E. globulus & $-43.99 \pm 10.18 * * \mathrm{a}$ \\
M. verticillata + Mentha sp. & $-55.80 \pm 4.14 * * * \mathrm{a}$ \\
Mentha sp. + A. citriodora & $-85.75 \pm 5.43 * * * \mathrm{a}$ \\
Mentha sp. + C. sativum & $-60.48 \pm 12.64 * * * \mathrm{a}$ \\
Control & $1.49 \pm 1.74 \mathrm{~b}$ \\
\hline
\end{tabular}

$*(\mathrm{P}<0.05)$ and ** $(\mathrm{P}<0.0 \mathrm{I}) ; * * * \quad(\mathrm{P}<0.00 \mathrm{I}) ; \mathrm{N}=5$ (significant response to experimental stimulus; paired-sample t-test). Mean responses to different treatments followed by different letters are significantly different (ANOVA $\mathrm{P}<0.05$, means comparison by Dunnett's test).

\section{Acknowledgements}

The authors thank FONCYT, CONICET and SECyT-UNC for financial support. Julieta Soledad Arena and María Laura Peschiutta have fellowships from CONICET. Julio Alberto Zygadlo is researcher of CONICET.

\section{Conflict of interest}

The author declares no conflict of interest.

\section{References}

1. Trematerra P, Ianiro R, Athanassiou CG, et al. Behavioral responses of Sitophilus zeamais Motschulsky adults to conditioned grain kernels. $J$ Stored Prod Res. 2013;53(2013):77-81.

2. Torres C, Silva G, Tapia M, et al. Insecticidal activity of Laurelia sempervirens (Ruiz \& Pav.) Tul. essential oil against Sitophilus zeamais Motschulsky. Chilean journal of agricultural research. 2014;74(4):421426.

3. Benhalima H, Chaudhry MQ, Mills KA, et al. Phosphine resistance in stored-product insects collected from various grain storage facilities in Morocco. J Stored Prod Res. 2004;40(3):241-249.

4. Pimentel D. Environmental and Economic Costs of the Application of Pesticides Primarily in the United States. Netherlands: Integrated Pest Management: Innovation-Development Process; 2009. p. 89-111.

5. Bakkali F, Averbeck S, Averbeck D, et al. Biological effects of essential oils-A review. Food Chem Toxicol. 2008;46(2):446-475.

6. Kim SI, Park C, Ohh MH, et al. Contact and fumigant activities of aromatic plant extracts and essential oils against Lasioderma serricorne (Coleoptera: Anobiidae). J Stored Prod Res. 2003;39(1):11-19.
7. Isman MB. Plant essential oils for pest and disease management. Crop Prot. 2000;19(8-10):603-608.

8. Koul O, Walia S, Dhaliwal GS. Essential Oils as Green Pesticides: Potential and Constraints. Biopestic Int. 2008;4(1):63-84.

9. Mossa ATH. Green Pesticides: Essential oils as biopesticides in insectpest management. J Environ Sci Technol. 2016;9(5):354-378.

10. Herrera JM, Zunino MP, Massuh Y, et al. Fumigant toxicity of five essential oils rich in ketones against Sitophilus zeamais (Motschulsky). Agriscientia. 2014;31(1):35-41.

11. Pimienta-Ramírez L, García-Rodríguez YM, Ríos-Ramírez EM, et al. Chemical composition and evaluation of the essential oil from Eupatorium glabratum as biopesticide against Sitophilus zeamais and several stored maize fungi. Journal of Essential Oil Research. 2016;28(2):113120.

12. Soujanya PL, Sekhar JC, Kumar P, et al. Potentiality of botanical agents for the management of post harvest insects of maize: a review. $J$ Food Sci Technol. 2016;53(5):2169-2184.

13. Tak JH, Isman MB. Enhanced cuticular penetration as the mechanism for synergy of insecticidal constituents of rosemary essential oil in Trichoplusia ni. Sci Rep. 2015;5:12690.

14. Das NG, Dhiman S, Talukdar PK, et al. Synergistic mosquito-repellent activity of Curcuma longa, Pogostemon heyneanus and Zanthoxylum limonella essential oils. J Infect Public Health. 2015;8(4):323-328.

15. Pavela R. Insecticidal properties of several essential oils on the house fly (Musca domestica L.). Phytother Res. 2008;22(2):274-278.

16. Benelli G, Pavela R, Canale A, et al. Acute larvicidal toxicity of five essential oils (Pinus nigra, Hyssopus officinalis, Satureja montana, Aloysia citrodora and Pelargonium graveolens) against the filariasis vector Culex quinquefasciatus: Synergistic and antagonistic effects. Parasitol Int. 2017;66(2):166-171.

17. Peschiutta ML, Arena JS, Ramirez Sanchez A, et al. Effectiveness of Mexican oregano essential oil from the Dominican Republic (Lippia graveolens) against maize pests (Sitophilus zeamais and Fusarium verticillioides). Agriscientia. 2016;33(2):89-97.

18. Sun YP, Johnson ER. Analysis of Joint Action of Insecticides Against House Flies. J Econ Entomol. 1960;53(5):887-892.

19. Wen H, Zhang Q, Cheng D, et al. Cassia oil as a substitute solvent for xylene for rotenone EC and its synergistic activities. Pestic Biochem Physiol. 2013;105(3):189-196.

20. Herrera JM, Pizzolitto RP, Zunino MP, et al. Effect of fungal volatile organic compounds on a fungus and an insect that damage stored maize. J Stored Prod Res. 2015;62:74-80.

21. Phillips T, Jiang XL, Burkholder WE, et al. Behavioral responses to food volatiles by two species of stored-product Coleoptera, Sitophilus oryzae (Curculionidae) and Tribolium castaneum (Tenebrionidae). J Chem Ecol. 1993;19(4):723-734.

22. Ritz C, Baty F, Streibig JC, et al. Dose-Response Analysis Using R. PLoS One. 2015;10(12):e0146021.

23. Team RC. R: A language and environment for statistical computing. Austria: R Foundation for Statistical Computing; 2013.

24. Palacios SM, Bertoni A, Rossi Y, et al. Insecticidal activity of essential oils from native medicinal plants of Central Argentina against the house fly, Musca domestica (L.). Parasitol Res. 2009;106(1):207-212.

25. Liu CH, Mishra AK, Tan RX, et al. Repellent and insecticidal activities of essential oils from Artemisia princeps and Cinnamomum camphora and their effect on seed germination of wheat and broad bean. Bioresour Technol. 2006;97(15):1969-1973.

26. Nerio LS, Olivero-Verbel J, Stashenko E. Repellent activity of essential oils:A review. Bioresour Technol. 2010;101(1):372-378. 